Marquette University

e-Publications@Marquette

Economics Faculty Research and Publications

Economics, Department of

$2-1-2008$

\title{
Openness and the Efficiency of FDI: A Panel Stochastic Production Frontier Study
}

Farrokh Nourzad

Marquette University, farrokh.nourzad@marquette.edu

Accepted version. International Advances in Economic Research, Volume 14, No. 1 (February 2008), DOI: $10.1007 /$ s1 1294-007-9128-5. (C) 2008 Springer. Used with permission.

Shareable Link. Provided by the Springer Nature SharedIt content-sharing initiative. 


\title{
Openness and the Efficiency of FDI: A Panel Stochastic Production Frontier Study
}

\author{
Author: Farrokh Nourzad
}

\begin{abstract}
This paper uses a stochastic translog production frontier to estimate technical inefficiency indices whose conditional mean is specified as a function of FDI and its interaction with openness of the economy. The model is estimated using an annual panel of 46 countries for the years, 1981-2001. The results suggest that increased FDI increases potential output in both developed and developing countries with the effect being more profound in the former. It is also found that increased FDI reduces technical inefficiencies the more open is the economy but that this effect holds only for developed economies. Thus qualified support is found for the "Bhagwati hypothesis" as the results reveal that the efficiency-enhancing effect of FDI depends not only on openness but also on the degree of development of the host country.
\end{abstract}

\section{Introduction}

In the past 30 years, we have witnessed worldwide trade liberalization, globalization of commerce and integration of a diverse set of economies. Open economies interact with one another in global product and capital markets. A country's trade balance captures the flow of goods and services traded on product markets. On the other hand, Foreign Direct Investment (FDI) and Foreign Portfolio Investment (FPI) represent the flow of physical and financial capital across national boundaries.

As far as the flow of capital is concerned, an issue of great concern to policy-makers, international organizations and economists is the potential effect of FDI on long-term economic growth. This subject has been studied extensively at both the theoretical and empirical levels (Aitken and Harrison 1989; Bengoa and Sanchez-Robles 2003; Blomstrom et al. 1992; Blonigen 2005; Borensztein et al. 1995; Chowdhury and Mavrotas 2006; Ciruelos and Wang 2005; Damijan et al. 2003; Frimpong and Oteng-Abayie 2006; Lipsey 2000, 2002; Kohpaiboon 2002). The general consensus appears to be that FDI contributes to economic growth through several channels, the most important of which is perhaps technology transfer.

In an influential book on the consequences of trade barriers, Bhagwati (1978) argued that FDI contributes to growth by enhancing economic efficiency and that this effect is larger in economies that promote outward-oriented trade policies (export promotion) relative to those that 1 Nourzad 
pursue inward-oriented strategies (import substitution). A number of studies have tested the "Bhagwati hypothesis" empirically and have found support for it (Balasubramanyam et al. 1996; Kohpaiboon 2002).

In this paper, we use a version of the stochastic production frontier model that allows us to estimate technical inefficiency indices and specify their conditional mean as a function of FDI and its interaction with the degree of openness of the economy so as to test the Bhagwati hypothesis. Using maximum likelihood and an annual panel of 46 countries in different stages of development for the years, 1981-2001, we jointly estimate a translog frontier and the associated mean technical inefficiencies. Our findings suggest that increased FDI increases potential output in both developed and developing countries but the effect is more profound in the former economies. We also find that increased FDI reduces technical inefficiencies the more open the economy, but that this effect holds only for developed economies. Thus, our findings provide qualified support for the Bhagwati hypothesis as they reveal that the efficiency-enhancing effect of FDI depends not only on openness to international trade but also on the degree of development of the host country.

"Econometric Methodology" presents the econometric approach used in this study. "Model, Data, and Results" specifies the empirical model, describes the data, and presents the results. "Summary and Suggestions for Further Research" summarizes this work and draws some conclusions.

\section{Econometric Methodology}

The stochastic production frontier (SPF) model can be presented in the context of the following log-linear functional form (Aigner et al. 1977; Meeusen and van den Broeck 1977):

$y_{i}=x_{i} \beta^{\prime}+\varepsilon_{i}, \quad i=1,2, \ldots, \mathrm{N}$

where $y_{i}$ is the logarithm of output of firm (country or industry) $i$; $x_{i}$ is a $1 \times(k+1)$ row vector whose first element is 1 and the remaining elements represent the logarithms of the $k$ inputs used by the $i$ th firm; and $\beta^{\prime}$ is a $(k+1) \times 1$ column vector of unknown parameters. The random error term, $\varepsilon_{i}$, is the difference of two independent random variables: a classical error term, $v_{i}$, and a non-negative random variable, $u_{i}$, that captures technical inefficiencies in firm $i$ :

$\varepsilon_{i}=v_{i}-u_{i}$

2 Nourzad 
where the error variance is given by:

$\sigma_{\varepsilon}^{2}=\sigma_{v}^{2}+\sigma^{2}$

While $v_{i}$ is typically assumed to be iid:n $\left(0, \sigma_{v}^{2}\right.$, the choice of a distribution for $u_{i}$ is arbitrary. In practice, the truncated normal, half normal, gamma and exponential distributions have been used. In this context, the technical efficiency of the ith firm, $T E_{i}$, is the ratio of observed output of firm $i$ divided by its efficient output represented by the estimated production frontier:

$\mathrm{TE}_{i}=y_{i} / \exp \left(\mathrm{x}_{\mathrm{i}} \beta^{\prime}\right)=\exp \left(-u_{i}\right)$

The technical efficiency coefficient in Eq. 4, which is bounded between zero and one, is unobservable because $u_{i}$ is unobservable. Battese and Coelli (1988) show that the best estimator of $\exp \left(-u_{i}\right)$ is its conditional expectation, $E\left[\exp \left(-u_{i}\right) \mid \varepsilon_{i}\right]$.

The above model, which implicitly assumes cross-sectional data, can easily be extended to panel data (Pitt and Lee 1981). The panel-data version of the SPF model is as follows:

$y_{i t}=x_{i t} \beta^{\prime}+\varepsilon_{i t} \quad i=1,2, \ldots, \mathrm{N} ; \quad t=1,2, \ldots, \mathrm{T}$

and:

$\varepsilon_{i t}=v_{i t}-u_{i t}$

Different versions of the panel-data SPF model have been proposed and estimated, ranging from models that assume the production inefficiencies, $u_{i t}$, are iid, to those that assume they are time invariant, to models in which technical inefficiencies vary over time. ${ }^{1}$ The specification used here is due to Battese and Coelli (1995) in which mean technical inefficiencies are affected by various factors across space and over time. This model consists of Eqs. 5 and 6 in which the $u_{i t}$ component of the error term in Eq. 6 is assumed to be a non-negative, independently distributed random variable, which is distributed as the truncation at zero of $n\left(\mu_{i t}, \sigma^{2}\right)$ where:

$\mu_{i t}=z_{i t} \delta^{\prime}+w_{i t}$

Here, $z_{i t}$ is a vector of factors that influence technical inefficiencies in firm $i$ in period $t$, 3 Nourzad 
and $\delta^{\prime}$ is a column vector of unknown parameters that are to be estimated.

Note that neither the basic SPF model in Eqs. 1-3 nor its panel-data version presented above can be estimated using OLS. This is because OLS assumes that $u=0$. As a result, the OLS estimate of $\beta_{0}$ would be biased downwards, estimates of $\beta_{1}, \beta_{2}, \ldots, \beta_{k}$ would be unbiased, but their standard errors would be biased. To avoid this, both specifications of the SPF model should be estimated using maximum likelihood. However, if $\gamma=\delta_{0}=\delta_{1}=\ldots \delta_{s}=0$, where $\gamma=\sigma^{2} / \sigma_{\varepsilon}^{2}$, there would be no technical inefficiencies and Eq. 5 can be estimated by OLS and the resulting parameter estimates would be efficient.

\section{Model, Data, and Results}

A common feature of empirical studies of the Bhagwati hypothesis is that they treat FDI as a production input. The rationale is that FDI increases output as new plants are constructed, equipments are acquired, and labor is hired. We follow this approach and specify a standard translog production function that includes the stock of FDI in the host country as a production input along with the stock of domestic capital and labor:

$$
\begin{aligned}
\ln Y_{i t}=\beta_{0}+ & \beta_{K} \ln K_{i t}+\beta_{L} \ln L_{i t}+\beta_{F} \ln F_{i t}+\frac{1}{2} \beta_{K K}\left(\ln K_{i t}\right)^{2}+\frac{1}{2} \beta_{L L}\left(\ln L_{i t}\right)^{2} \\
& +\frac{1}{2} \beta_{F F}\left(\ln F_{i t}\right)^{2}+\beta_{K L}\left(\ln K_{i t} \times \ln L_{i t}\right)+\beta_{K F}\left(\ln K_{i t} \times \ln F_{i t}\right)+\beta_{L F}\left(\ln L_{i t} \times \ln F_{i t}\right) \\
& +\beta_{K t}\left(t \times \ln K_{i t}\right)+\beta_{L t}\left(t \times \ln L_{i t}\right)+\beta_{F t}\left(t \times \ln F_{i t}\right)+\beta_{t} t+\frac{1}{2} \beta_{t t} t^{2}+\varepsilon_{i t}
\end{aligned}
$$

where $Y$ is output, $K$ is domestic capital stock, $F$ is the stock of foreign direct investment, $L$ denotes input of labor, $i$ is the country index and $t$ is the time index. The term $\varepsilon_{i t}$ is the same as the error-components in Eq. 6, where we assume the $u_{i t}$ component, which represents technical inefficiency, follows the generalized truncated-normal distribution. In order to test the Bhagwati hypothesis, we specify the conditional mean, $\mu_{i t}$, of the technical inefficiencies, $u_{i t}$, as a function of FDI in each country in the sample $\left(F_{i t}\right)$ and the interaction between $F_{i t}$ and the degree of openness of the economy to international trade $\left(O_{i t}\right)$ :

$\mu_{\mathrm{tit}}=\delta_{0}+\delta_{1} \operatorname{lnF}_{\mathrm{it}}+\delta_{2}\left(\operatorname{lnF}_{\mathrm{it}} \times \mathrm{O}_{\mathrm{it}}\right)+w_{i t}$

Given that FDI already enters the production function in Eq. 8 as an input, its inclusion in 4 Nourzad 
Eq. 9 should capture its other effects such as transfer of technology and managerial skills. As Damijan et al. (2003) note, the direct effect of FDI-induced technology transfer is to enhance the efficiency with which the economy utilizes its existing scarce resources, which is what is being modeled by Eq. 9. ${ }^{2}$ This is consistent with Schumpeter's(1912, p. 68) view of development as "consist[ing] primarily in employing existing resources in a different way, in doing new things with them, irrespective of whether those resources increase or not." [Emphasis added]

We estimate Eqs. 8 and 9 jointly using maximum likelihood and an annual panel of 46 countries of which 28 are developing and 18 are developed covering the period from 1981 through 2001. ${ }^{3,4}$ We quantify the arguments of these two equations as follows. For output we use GDP in constant local currency units. For capital, we use fixed business investment in constant local currency units. Labor is represented by the labor force. For FDI, we use the ratio of the inbound flow of FDI to GDP, and we quantify openness in terms of the ratio of imports plus exports to GDP. ${ }^{5,6}$

In recognition of the fact that our sample contains countries in two distinctly different phases of economic development, we construct a dummy variable, D, that equals one for the 28 developing countries in the sample and takes on a zero value for the 18 developed nations. We include this variable both additively as an intercept dummy and multiplicatively as a series of slope dummies by interacting it with the other variables in the translog production function and in the associated mean inefficiency equation.

We estimate three separate production frontiers that differ with respect to what they include as determinants of technical inefficiency. The first equation considers FDI, F, the dummy variable for developing countries, $D$ and the interaction terms between $F$ and $D$. The second equation includes two additional regressors in the inefficiency equation: the interaction of FDI and openness and a three-way interaction term between the development dummy, FDI, and openness, $\mathrm{D} \times \mathrm{F} \times 0$. The rationale for the inclusion of the latter interaction term is to test whether the Bhagwati hypothesis is sensitive to the degree of development of the host country. The sign and significance of the estimated coefficient on the interaction term between FDI and openness allow us to test the Bhagwati hypothesis, which would be supported if it is found to be negative and statistically significant implying reductions in inefficiencies with increased FDI and openness above and beyond the contribution of FDI alone. Finally, recognizing the symmetrical nature of interaction terms, we examine the possibility that the $\mathrm{F} \times 0$ interaction term might capture the effect of openness rather than FDI by replacing FDI with openness in the inefficiency equation.

5 Nourzad 
The results from estimating the three stochastic production frontiers are reported in Tables 1, 2 and 3, respectively. Each of these tables consists of three sections. The top section contains the results of estimating the translog production frontier in Eq. 8. The middle section reports the corresponding estimation results for the mean inefficiency coefficients equation. The bottom portion includes a few diagnostic statistics.

We begin our discussion of the results with the figures in the top portions of these tables representing the output effects of capital, labor, and FDI. The estimated coefficients associated with capital and labor are positive and statistically significant at the $1 \%$ level in all three tables. This is also the case with the estimated coefficient on the product of labor and capital variables implying that they are cooperative inputs. The estimated coefficients on the squared $\operatorname{lnK}$ and $\operatorname{lnL}$ are negative and statistically significant in all equations suggesting diminishing returns to both inputs.

Considering the estimated coefficients on $\mathrm{t}$ and $t^{2}$, we observe that they are consistently negative but are not statistically significantly different from zero. The interaction term involving the trend variable and input of capital is statistically significantly positive in all cases implying that the output elasticity of capital has increased over time. On the other hand, the interaction term between the trend variable and labor is negative across all three models but is only statistically significant at the $10 \%$ level in Tables 2 and 3 . In the top portions of the three tables, the parameter estimate associated with the dummy variable for developing countries is positive and statistically significant, a result that is unexpected and hard to explain. However, in all three tables the two interaction terms involving the dummy variable and the inputs of labor and capital are statistically significantly negative implying that both inputs have a smaller elasticity in developing countries.

We now turn to the variable of interest, FDI, in the top portion of Tables 1, 2 and 3, where we observe that its estimated coefficient is positive and highly statistically significant in all cases. This result, which is consistent with much of the empirical literature using the production function approach, suggests that FDI does indeed serve as a productive input. Moreover, as with the traditional inputs of labor and domestic capital, FDI appears to be subject to diminishing returns given that in all cases, the parameter estimates on squared FDI are negative and significant. The parameter estimates on the interaction of FDI and domestic capital are negative throughout and significant in Tables 1 and 3, which may be taken to indicate that these two inputs are competitive. The same is not true of FDI and labor where the estimated effect, while negative, is not significantly different from zero.

6 Nourzad 
The estimated coefficients on the interaction of FDI and the trend variable, which are consistently positive, are not statistically significant at conventional levels. Similarly, the estimated parameters associated with the interaction of FDI and the dummy variable for developing countries is not statistically significant in any of the three cases. This is an interesting result in view of the fact that we find the output elasticity of traditional inputs to be lower in developing countries but that of FDI is not different between the two sets of countries.

Next, we test the hypothesis that there are no technical inefficiencies, $\gamma=\delta^{\prime}=0$. The test statistic is a likelihood-ratio (LR) which has a mixed chi-square distribution with degrees of freedom equal to the number of $\delta$ 's. The results in the lower portion of Tables 1, 2 and 3 indicate that the LR statistics for all three models are highly significant indicating that there are significant technical inefficiencies in the countries in our sample. Moreover, in all cases the variance parameter, $\gamma$, is nearly equal to one suggesting that almost all of the variation in the random error term in Eq. 8 is due to technical inefficiencies, $u_{i t}$.

Now consider the results in the middle section of Tables 1, 2 and 3, which pertain to the effect of FDI and other variables on mean inefficiency coefficients. In Table 1, the estimated coefficient on FDI is negative and statistically significant at the $10 \%$ level of significance. This suggests that increased inflow of FDI to developed nations reduces inefficiencies in these countries. The estimated coefficient associated with the product of FDI and the developing countries dummy variable is also negative and significant at the $1 \%$ level. Thus, it appears that an increase in inbound FDI to the developing countries has a larger favorable effect on production inefficiencies than in developed nations. Note that the estimated coefficient on the dummy variable itself is positive and significant indicating that technical inefficiencies are larger in developing nations than those of the developed economies.

Now consider the results in the middle section of Table 2 where we include the interaction term between FDI and openness and that between these two variables and the development dummy as additional regressors allowing us to test the Bhagwati hypothesis. We observe that the estimated coefficient on FDI, which was negative in Table 1, is now positive and significant implying that inbound FDI into developed economies actually increases technical inefficiencies in these countries, which is a curious and puzzling finding. In contrast, the negative and significant estimate associated with the dummy $\times$ FDI interaction term suggests that in developing countries increased FDI reduces technical inefficiencies. We also find that the estimated effect of the interaction between FDI and openness is negative and significant for developed economies, which supports the Bhagwati hypothesis. ${ }^{7}$

7 Nourzad 
However, the hypothesis is not supported for developing economies because the coefficient on the three-way interaction term between FDI, openness, and the developing dummy variable is positive and significant indicating that in developing countries the efficiency-enhancing effect of FDI diminishes with increased openness. This may be explained in terms of lack of an efficient infrastructure for facilitating the dissemination of technological and managerial know-how associated with the inflow of FDI to the economy. It can also be explained at least in part by the potential lack of a minimum level of human capital for the absorption of this know-how.

Finally, the results in Table 3 where FDI is replaced with openness in the inefficiency equation reveal that the estimated coefficient on the dummy variable for developing countries, which is once again positive, is statistically significant.

Moreover, the dummy $\times$ openness interaction term is also positive and significant, which means that by itself increased openness to international trade reduces productive efficiency in developing economies. Note, however, that neither the estimated coefficient on FDIxopenness nor that associated with the interaction term involving openness and development dummy is statistically significant. This gives us confidence regarding our earlier findings in the middle section of Table 2 concerning the efficiency effect of FDI through openness.

\section{Summary and Suggestions for Further Research}

This paper used a panel-data stochastic production frontier model to estimate technical inefficiency indices whose conditional mean was expressed as a function of FDI and its interaction with the degree of openness of the economy so as to test the Bhagwati hypothesis. Using maximum likelihood and an annual panel of 46 countries of which 28 are developing and 18 are developed for the years, 1981-2001, we jointly estimated a translog frontier and the associated mean technical inefficiencies. Our findings suggest that increased FDI increases output in both developed and developing countries but the effect is more profound in the former economies. We also find that increased FDI reduces technical inefficiencies the more open is the economy. This effect holds only for developed economies. Thus our findings provide qualified support for the Bhagwati hypothesis as they reveal that the result depends not only on openness to international trade but also on the degree of development of the host country.

There are a number of ways in which this work can be improved and extended. One is to use separate measures of trade strategies, distinguishing between import-substitution and export promotion regimes such as country specific, tariff- and non tariff-based indices of trade

8 Nourzad 
liberalization. Another possibility is to consider imperfections in the exchange market such as rate controls, which may be captured at least partially by black market premium in developing countries. Finally, it may be a fruitful exercise to include in the study a measure of human capital and its interaction with inbound FDI.

\section{Notes}

- Presented at the Sixty-first International Atlantic Economic Conference Berlin, Germany15-19 March 2006.

- This research was partially funded through a grant from Marquette University College of Business Administration Miles fund and a grant for the Institute for Global Economic Affairs.

- F. Nourzad (mail) Economics Department, Marquette University, P.O. Box 1881, Milwaukee, WI 53201-1881, USA; (e-mail): farrokh.nourzad@marquette.edu

- ${ }^{1}$ For more on different specifications of the panel stochastic production frontier model see Coelli et al. (1998, pp. 202-204).

- ${ }^{2}$ In addition to the direct effect of technology transfer associated with FDI, Damijan et al. (2003) also point to spillover effects through intra-industry or "horizontal" and inter-industry or "vertical" channels.

- ${ }^{3}$ The developing countries in the sample consists of Algeria, Argentina, Bangladesh, Brazil, Chile, China, Colombia, Costa Rica, Dominican Republic, Ecuador, Guatemala, Honduras, India, Indonesia, Kenya, Malaysia, Mexico, Morocco, Pakistan, Panama, Paraguay, Peru, Philippines, Sierra Leone, Swaziland, Thailand, Venezuela, and Zambia. The developed countries are Australia, Austria, Belgium, Canada, Denmark, Finland, France, Greece, Ireland, Italy, Japan, Netherlands, New Zealand, Portugal, Spain, Sweden, United Kingdom, and United States. All data are from the United Nations World Development Indicators.

- ${ }^{4}$ We use the FRONTIER software, version 4.1 by Coelli (1996) to estimate the translog production function and technical inefficiencies.

- ${ }^{5}$ Given that these two variables are measured in percentages, we do not express them in the logarithmic form.

- ${ }^{6}$ Other measures of openness include the ratio of imports to GDP (Romer 1993); the index constructed by Dollar (1992) based on purchasing power parity and relative prices; black market premium; and indices of trade liberalization based on tariff and non-tariff,

9 Nourzad 
country-specific information.

- ${ }^{7}$ Note, however, that for the developed countries the sum of the positive coefficient on FDI (0.192) and that of the interaction between FDI and openness $(-0.001)$ is still positive pointing to increased inefficiency in these economies from FDI inflow.

\section{References}

Aigner, D. J., Lovell, C. A. K., \& Schmidt, P. (1977). Formulation and estimation of stochastic frontier production function models. Journal of Econometrics, 6, 21-37.

Aitken, B., \& Harrison, A. E. (1989). Do domestic firms benefit from foreign investment? Evidence from Venezuela. American Economic Review, 89(3), 605-618.

Balasubramanyam, V. M., Salisu, M., \& Sapsford, D. (1996). Foreign direct investment and growth in EP and IS countries. Economic Journal, 106, 92-105.

Battese, G. E., \& Coelli, T. J. (1988). Prediction of firm-level technical efficiencies with a generalized frontier production function and panel data. Journal of Econometrics, 38, 387-399.

Battese, G. E., \& Coelli, T. J. (1995). A model for technical inefficiency effects in a stochastic production frontier for panel data. Empirical Economics, 20(2), 325-332.

Bengoa, M., \& Sanchez-Robles, B. (2003). Foreign direct investment, economic freedom, and growth: New evidence from Latin America. European Journal of Political Economy, 19(3), 529-545.

Bhagwati, J. N. (1978). Anatomy and Consequences of Exchange Control Regimes. Studies in International Economic Relations. New York: NBER.

Blomstrom, M., Zejan, M., \& Lipsey, R. E. (1992). What explains developing country growth? National Bureau of Economic Research Working Paper: 4132.

Blonigen, B. A. (2005). A review of the empirical literature on FDI determinants. Atlantic Economic Journal, 33(4), 383-403.

Borensztein, E., De Gregorio, J., \& Lee, J. (1995). How does foreign direct investment affect economic growth?" National Bureau of Economic Research, Working Paper: 5057.

Chowdhury, A. R., \& Mavrotas, G. (2006). FDI and growth: What causes what? The World Economy, 29 (1), 9-19.

Ciruelos, A., \& Wang, M. (2005). International technology diffusion: Effects of trade and FDI. Atlantic Economic Journal, 33(4), 437-449.

Coelli, T. J. (1996). A guide to FRONTIER Version 4.1: A computer program for stochastic

10 Nourzad 
production and cost function estimation. Centre for efficiency and productivity analysis, University of New England, Armidale, NSW, Australia, Working paper: 96/07.

Coelli, T. J., Rao, D. S. P., \& Battese, G. E. (1998). An introduction to efficiency and productivity analysis. Boston: Kluwer Academic Publishers.

Damijan, J. P. Knell, M., Majcen, B., \& Rojec, M. (2003). Technology transfer through FDI in Top-10 transition countries: How important are direct effects, horizontal and vertical spillovers? The University of Michigan Business School, William Davidson Working Paper: 549.

Dollar, D. (1992). Outward-oriented developing economies really do grow more rapidly: Evidence from 95 LDCs, 1976-1985. Economic Development and Cultural Change, 40(3), 523-544.

Frimpong, J. M., \& Oteng-Abayie, E. F. (2006). Bivariate causality analysis between FDI inflows and economic growth in Ghana." Munich University, MPRA Paper No. 351.

Kohpaiboon, A. (2002). Foreign trade regime and FDI-growth nexus: A case study of Thailand. Department of Economics, Australian National University, Working Papers.

Lipsey, R. E. (2000). Inward FDI and economic growth in developing countries. Transitional Corporations, 9(1), 61-95.

Lipsey, R. E. (2002). Home and host country effects of FDI. National Bureau of Economic Research Working Papers: 9293.

Meeusen, W., \& van den Broeck, J. (1977). Efficiency estimation from Cobb-Douglas production functions with composed error. International Economic Review, 18(2), 435-444.

Pitt, M. M., \& Lee, L. (1981). Measurement and sources of technical Inefficiency in the Indonesian weaving industry. Journal of Development Economics, 9,43-64.

Romer, D. (1993). Openness and inflation: Theory and evidence. Quarterly Journal of Economics, 108(4), 869-903.

Schumpeter, J. (1912). Theorie der Wirtschaftlichen Entwicklug (The Theory of Economic Development,) 1934 translated edition. Cambridge, Massachusetts: Harvard University Press.

11 Nourzad 


\section{Appendix}

Table 1

Maximum likelihood estimates of stochastic production frontier with mean inefficiency coefficients as a function of F, D, DxF annual panel of 46 countries: 1981-2001

\begin{tabular}{|c|c|c|}
\hline Variables & Estimates & Asymptotic t-Ratios \\
\hline \multicolumn{3}{|c|}{ Dependent variable $=\ln Y$} \\
\hline Intercept & 7.089 & $6.254^{* * * *}$ \\
\hline $\ln K$ & 0.455 & $7.312^{* * * *}$ \\
\hline $\ln L$ & 0.573 & $4.163^{* * *}$ \\
\hline$F$ & 0.175 & $4.113^{* * * *}$ \\
\hline$(\ln K)^{2}$ & -0.048 & $-17.473^{* * *}$ \\
\hline$(\ln L)^{2}$ & -0.090 & $-12.227^{* * *}$ \\
\hline$F^{2}$ & -0.0001 & $-3.572^{* * * *}$ \\
\hline $\ln \mathrm{K} \times \ln L$ & 0.130 & $14.110^{* * *}$ \\
\hline $\ln \mathbf{K} \times \mathbf{F}$ & -0.005 & $-2.118^{* *}$ \\
\hline $\ln L \times \mathbf{F}$ & -0.004 & -1.252 \\
\hline$t$ & -0.001 & -0.221 \\
\hline$t^{2}$ & -0.0002 & -0.823 \\
\hline$t \times \ln \mathrm{K}$ & 0.002 & $2.798^{* * *}$ \\
\hline$t \times \ln L$ & -0.002 & -1.398 \\
\hline$t \times F$ & 0.001 & 1.350 \\
\hline$D$ & 2.853 & $8.811^{* * * *}$ \\
\hline$D \times \ln \mathrm{K}$ & -0.067 & $-4.750^{* * * * * *}$ \\
\hline$D \times \ln L$ & -0.096 & $-4.839^{* * * *}$ \\
\hline$D \times F$ & -0.002 & -0.197 \\
\hline \multicolumn{3}{|c|}{ Dependent variable $=$ mean inefficiency coefficients } \\
\hline Intercept & -7.613 & $-8.545^{* * *}$ \\
\hline$F$ & -0.028 & $-1.767^{*}$ \\
\hline$D$ & 8.448 & 9.989 \\
\hline$D \times F$ & -0.080 & $-2.693^{* * *}$ \\
\hline$\sigma^{2}$ & 0.865 & $13.994^{* * *}$ \\
\hline$\gamma$ & 0.992 & $677.174^{* * * *}$ \\
\hline $\operatorname{LR}(d f=6)$ & $855.651^{* * * *}$ & \\
\hline LLF & 350.094 & \\
\hline
\end{tabular}

${ }^{* * *}$ Significant at the $1 \%$ level

${ }^{* *}$ Significant at the $5 \%$ level

${ }^{*}$ Significant at the $10 \%$ level

$K$, real fixed business investment; $L$, labor force; $F$, inbound FDI as a percent of GDP; $O$, sum of imports and exports of goods and services as a percent of GDP; $D$, dummy variable for the 28 developing countries in the sample 


\section{Table 2}

Maximum likelihood estimates of stochastic production frontier with mean inefficiency coefficients as a function of $F, D, D \times O, F \times O, F \times O \times D$ annual panel of 46 countries: 1981-2001

\begin{tabular}{|c|c|c|}
\hline Variables & Estimates & Asymptotic t-Ratios \\
\hline \multicolumn{3}{|c|}{ Dependent variable $=\ln Y$} \\
\hline Intercept & 7.944 & $6.766^{* * *}$ \\
\hline $\ln K$ & 0.423 & $6.535^{* * * *}$ \\
\hline $\ln L$ & 0.507 & $4.108^{* * * *}$ \\
\hline $\mathbf{F}$ & 0.149 & $3.058^{* * * *}$ \\
\hline$(\ln K)^{2}$ & -0.051 & $-18.607^{* * * *}$ \\
\hline$(\ln L)^{2}$ & -0.098 & $-13.182^{* * * *}$ \\
\hline $\mathbf{F}^{2}$ & -0.0001 & $-3.583^{* * *}$ \\
\hline $\ln \mathrm{K} \times \ln \mathrm{L}$ & 0.143 & $15.090^{* * * *}$ \\
\hline $\ln K \times \mathbf{F}$ & -0.004 & -1.429 \\
\hline $\ln L \times F$ & -0.004 & -1.116 \\
\hline$t$ & -0.001 & -0.049 \\
\hline$t^{2}$ & -0.0002 & -1.169 \\
\hline$t \times \ln K$ & 0.002 & $2.626^{* * * *}$ \\
\hline$t \times \ln L$ & -0.002 & $-1.736^{*}$ \\
\hline$t \times F$ & 0.001 & 1.301 \\
\hline D & 2.879 & $9.306^{* * * *}$ \\
\hline $\mathrm{D} \times \ln \mathrm{K}$ & -0.066 & $-5.109^{* * * *}$ \\
\hline $\mathrm{D} \times \ln \mathrm{L}$ & -0.097 & $-5.058^{* * * *}$ \\
\hline $\mathrm{D} \times \mathrm{F}$ & -0.006 & -0.576 \\
\hline \multicolumn{3}{|c|}{ Dependent variable $=$ mean inefficiency coefficients } \\
\hline Intercept & -7.701 & $-21.873^{* * *}$ \\
\hline $\mathbf{F}$ & 0.192 & $2.626^{* * * *}$ \\
\hline D & 8.559 & $20.463^{* * * *}$ \\
\hline $\mathrm{D} \times \mathrm{F}$ & -0.305 & $-4.110^{* * * *}$ \\
\hline $\mathrm{F} \times \mathrm{O}$ & -0.001 & $-2.451^{* * * *}$ \\
\hline $\mathbf{F} \times \mathbf{O} \times \mathbf{D}$ & 0.002 & $3.701^{* * * *}$ \\
\hline$\sigma^{2}$ & 0.859 & $18.671^{* * * *}$ \\
\hline$\gamma$ & 0.992 & $689.268^{* * *}$ \\
\hline $\mathrm{LR}(\mathrm{df}=9)$ & $858.385^{* * * *}$ & \\
\hline LLF & 349.575 & \\
\hline
\end{tabular}

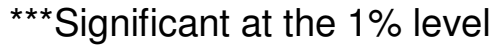

${ }^{* *}$ Significant at the $5 \%$ level

*Significant at the $10 \%$ level

$K$, real fixed business investment; $L$, labor force; $F$, inbound FDI as a percent of GDP; $O$, sum of imports and exports of goods and services as a percent of GDP; D, dummy variable for the 28 developing countries in the sample 


\section{Table 3}

Maximum likelihood estimates of stochastic production frontier with mean inefficiency coefficients as a function of $O, D, D \times O, F \times O, F \times O \times D$ annual panel of 46 countries: 1981-2001

\begin{tabular}{|c|c|c|}
\hline Variables & Estimates & Asymptotic t-Ratios \\
\hline \multicolumn{3}{|c|}{ Dependent variable $=\ln Y$} \\
\hline Intercept & 7.747 & $7.078^{* * * *}$ \\
\hline $\ln K$ & 0.458 & $6.577^{* * * *}$ \\
\hline $\ln L$ & 0.472 & $3.932^{* * * *}$ \\
\hline $\mathbf{F}$ & 0.186 & $3.991^{* * * *}$ \\
\hline$(\ln K)^{2}$ & -0.052 & $-17.253^{* * *}$ \\
\hline$(\ln L)^{2}$ & -0.97 & $10.855^{* * *}$ \\
\hline $\mathrm{F}^{2}$ & -0.0001 & $-3.585^{* * * *}$ \\
\hline $\ln K \times \ln L$ & 0.142 & $13.206^{* * * *}$ \\
\hline $\ln \mathbf{K} \times \mathbf{F}$ & -0.006 & $2.803^{* * *}$ \\
\hline $\ln L \times \mathbf{F}$ & -0.003 & -0.845 \\
\hline $\mathrm{t}$ & -0.001 & -0.077 \\
\hline$t^{2}$ & -0.0002 & -0.868 \\
\hline$t \times \ln K$ & 0.002 & $2.631^{* * * *}$ \\
\hline$t \times \ln L$ & -0.002 & $-1.701^{*}$ \\
\hline$t \times F$ & 0.001 & 1.045 \\
\hline $\mathrm{D}$ & 3.292 & $8.926^{* * * *}$ \\
\hline $\mathrm{D} \times \ln \mathrm{K}$ & -0.069 & $-5.404^{* * * *}$ \\
\hline $\mathrm{D} \times \ln \mathrm{L}$ & -0.119 & $5.853^{* * * *}$ \\
\hline $\mathbf{D} \times \mathbf{F}$ & 0.010 & 1.088 \\
\hline \multicolumn{3}{|c|}{ Dependent variable $=$ Mean inefficiency voefficients } \\
\hline Intercept & -7.708 & $31.961^{* * *}$ \\
\hline 0 & -0.00001 & -0.008 \\
\hline $\mathrm{D}$ & 8.254 & $34.313^{* * * *}$ \\
\hline $\mathrm{D} \times \mathrm{O}$ & 0.005 & $2.191^{* * * *}$ \\
\hline FO & 0.000001 & 0.004 \\
\hline $\mathrm{D} \times \mathrm{O} \times \mathbf{F}$ & -0.0003 & -0.924 \\
\hline$\sigma^{2}$ & 0.886 & $19.875^{* * *}$ \\
\hline$\gamma$ & 0.993 & $665.275^{* * *}$ \\
\hline $\mathrm{LR}(\mathrm{df}=7)$ & $848.825^{* * * *}$ & \\
\hline LLF & -350.188 & \\
\hline
\end{tabular}

*** Significant at the $1 \%$ level

${ }^{* *}$ Significant at the $5 \%$ level

*Significant at the $5 \%$ level

$K$, real fixed business investment; $L$, labor force; $F$, inbound FDI as a percent of GDP; $O$, sum of imports and exports of goods and services as a percent of GDP; $D$, dummy variable for the 28 developing countries in the sample 